\title{
THE ROLE, FUNCTIONS AND PERFORMANCE OF BOTSWANA'S INDEPENDENT ELECTORAL COMMISSION
}

\author{
By \\ Balefi Tsie \\ Professor Balefi Tsie is a member of the Botswana Independent Electoral Commission \\ and teaches in the Department of Political and Administrative Studies, \\ University of Botswana, Private Bag 0022 Gaborone Botswana \\ Tel: +267 3552730; Fax: +267585 5099; e-mail: TSIEB@mopipi.ub.bw
}

\section{INTRODUCTION}

From the first pre-independence general election of March 1965 elections in Botswana were run by the Supervisor of Elections, who fell under the Office of the President. As time went on the public, particularly members of the opposition parties, perceived the Supervisor of Elections as being a government employee controlled by the ruling party, or at least under its influence.

Government heeded the call of opposition parties for the formation of an Independent Electoral Commission (IEC) to run the elections and, in 1997, the Constitution was amended to accommodate the establishment of such a body to replace the office of the Supervisor of Elections. Section 65A of the Constitution of Botswana sets out the composition of the Commission.

\section{THE COMMISSION}

The IEC consists of a chairperson and a deputy chairperson appointed directly by the Judicial Service Commission and five other members appointed from a list of persons recommended by the All Party Conference. Section 65A stipulates that the chairperson shall be a judge of the high court, while the deputy chairperson shall be a legal practitioner.

The Commission is an autonomous, non-partisan body whose primary purpose is to conduct free, fair and correct elections efficiently and effectively in accordance with universally accepted electoral principles and practices.

Its goals are:

- To establish an effective voting mechanism.

- To ensure that voters are motivated to vote, informed about how to vote and officially registered to vote. 
- To facilitate the creation of a climate in which political parties can freely communicate messages to the electorate to enable the electorate to make informed choices.

Section 65A defines the functions of the Commission as follows:

- To conduct and supervise elections of members of the National Assembly and of a Local Authority.

- To conduct a referendum.

- To ensure that elections are conducted efficiently, properly, freely and fairly.

- To give instructions and directions to the Secretary of the Commission (who is appointed under Section 66) with regard to the exercise of his functions under the Electoral Law prescribed by an Act of Parliament.

- To ensure that elections are conducted efficiently, properly, freely and fairly.

- To perform such other functions as may be prescribed by an Act of Parliament.

The Secretary, who is the Chief Executive Officer of the Commission, is appointed by the President under Section 66 of the Constitution and his/her responsibilities include:

- Management and administration of the Commission.

- Implementation of decisions of the Commission.

- Supervision of registration of voters.

- Conduct of National Assembly elections.

- Conduct of local authority elections.

The Secretary is assisted by such staff as the Commission may appoint. The staff complement includes twenty principal elections officers based in the electoral regions. Each officer is assisted by an administrative assistant.

The twenty District Offices (Regional Elections Offices) were created with a view to linking the districts with headquarters and making the IEC's presence felt at grassroots level. Seventeen of the offices are fully operational and form a critical component of the continuous voter education outreach programme.

The main functions of the Regional Officers are to co-ordinate registration and elections and to promote voter education initiatives. In this regard they:

- Make preparations for the registration of voters.

- Recruit and supervise registration officers.

- Arrange for and mount training sessions for the registration officers in conjunction with the Headquarters.

- Prepare estimates for the registration of voters, including estimates for polling days.

- Maintain accurate voters' rolls.

- Arrange all elections, including by-elections and referenda. 
- Organise within their regions, in conjunction with Head Office and district authorities, the requisition of the materials and financial resources needed for election processes.

There is no interference whatsoever by the government in the operations of the IEC, even though the state finances the Commission. There is a clear understanding that the IEC is a public institution and, therefore, that it must be financed by public funds, whose management and use has been conferred on the government of the day by popular vote. It is also understood that the money financing the IEC comes not from the ruling party but from the public purse.

The Commission is required by law to account for the funds it uses through the Public Accounts Committee of Parliament. It is the Minister responsible for Presidential Affairs and Public Administration who appears before the Committee to explain in detail the use of the funds.

\section{Promoting DeMOCRACY}

The purpose of elections is to entrench popular control over decision-making processes at national and local levels of government and to ensure equality of political rights and effective representation for all eligible voters. It is therefore critical that the electoral process is managed in a manner that promotes maximum participation by all stakeholders in voter education programme planning and implementation. To this end, the IEC in Botswana has conceived a comprehensive voter education programme, some of which is in the planning stages and some of which is already operational.

The voter education programme is expected to set up national organisations, institutions or foundations, and establish operational guidelines for collaboration to take democratisation and the electoral process forward. Links will be forged with non-governmental organisations (NGOs), community-based organisations (CBOs), educational institutions, government departments, political parties, community leaders, churches, the private sector and the international donor community. Training workshops, seminars and conferences will form the basis of interactive involvement of people in democracy development and nation building. In this way the democratic reform agenda will be home grown and nationally driven.

The involvement of selected civil society organisations in the training and dissemination of voter education, the utilisation of school children in dramatising democratic situations, and interaction using pictorial representations and other teaching-learning situations will enable people to distinguish and appreciate the difference between democratic and non-democratic practices.

In the long term, democracy development initiatives will be introduced in schools, even at lower elementary levels, for democracy begins when a child is born. Democracy is about tolerance and co-existence; about creating a climate where opinions and viewpoints of others are respected and differences in perceptions 
accepted by all. With education and training our people can judge fairly, and consciously make informed decisions and choices.

The IEC hopes to initiate and promote interaction among the electorate, political parties, the media and civil society to institutionalise democratic practices and values. The research component of the Commission's information, education and communication programmes will conduct rapid democracy assessment surveys to feed into the democratic reform agenda.

The regional officers will serve as a link between IEC headquarters and the regions, to facilitate information flow to the intended audience. The tasks of the IEC national and district structures, in general, are to:

- Initiate and oversee the implementation of the democratic reform agenda.

- Disseminate the assessment reports (rapid assessment survey results) nationally, especially at the grassroots level.

- Encourage national and local debate about problem areas that are identified in assessment reports and recommendations arising from evaluation research.

- Engage in the promotion and regular assessment of the democratisation process.

- Ensure that there is a continuous flow of information from field experiences to IEC headquarters and that, through networking and sharing experiences with its counterparts in the region and abroad, the IEC Secretariat contributes to the advancement of democracy in the country.

\section{VOTER EDUCATION}

Voter education is a form of education in support of elections and a means of ensuring that voters are prepared and enabled to participate in electoral politics. It essentially revolves around the mechanics of how to vote - though, of course, it also covers elements of why it is necessary to vote. Voter education programmes aim to provide a basic understanding of election practices and procedures and knowledge of party symbols. Their other major goal is to cultivate trust and confidence in electoral processes so that the processes are seen and believed to be the most appropriate and effective means of choosing a government and a way of approving policies and socio-economic programmes that are relevant to the needs of the voter. Thus, the education of voters is not just about political issues -important as these are - it is also aimed at giving them the kind of understanding that puts them in a position to compare parties and programmes when they ultimately vote.

Voter education programmes are usually planned, developed and implemented by an electoral authority/elections administration officials in collaboration with political parties and civil society organisations. The private sector and the media may be sub-contracted to produce or publish voter education materials and can also voluntarily engage in voter education activities on their own. Various government departments responsible for informing and educating citizens are also 
involved in voter education. Youths and children, especially, can be encouraged to participate in elections by engaging in mock election games where they run for election or campaign for others, to promote a spirit of healthy competition.

The IEC's voter education programme is a very ambitious one indeed - not surprisingly, since it seeks to combat voter apathy, which the IEC views as a serious threat to vibrant democracy. It is therefore fitting that the IEC should relentlessly pursue voter education throughout the country - vast and sparsely populated as it is.

The Commission launched a massive study on voter apathy. The study funded to the tune of close to US\$300 000 - was conducted by the Democracy Research Project of the University of Botswana and its findings have been integrated into the IEC's voter education programme which is now under way.

\section{SOCIAL RESEARCH}

One way of ensuring that the opinions and views of voters about matters of electoral policy and procedures are known and appropriately integrated into recommendations for policy changes is to undertake social research. Social research allows for a greater appreciation of the level of understanding (or the lack thereof) among electorates of electoral procedures such as voter registration, vote casting, nominations, democracy as a way of governing and the role of elected officials. Social research also allows concerned bodies to identify reasons for voter apathy, especially among the youth.

In Botswana, young people did not vote in large numbers in the 1999 general election, the first in which the voting age was lowered to eighteen years from twenty-one.

\section{The General Election of October 1999}

Despite limited time and human resources, the IEC of Botswana was able to arrange for and deliver the October 1999 general election without any major problems and in a manner described by international and local observers as 'free and fair'. Although a few results were challenged in the High Court, this was mostly the result of a lack of appreciation of procedures or of flawed interpretation of the Electoral Act and other legislation governing elections. Given that this was the first election to have been run by the IEC, the administration and results should go down in history as a notable achievement. Since 1999 the IEC has run several byelections at ward level. These, too, have been run properly and efficiently.

\section{ELECTORAL SYSTEM}

Botswana's electoral system is a constituency-based 'first-past-the-post' system. The country is divided into forty constituencies, which are likely to increase to at least forty-five after the next population census. A census is conducted every ten 
years, after which a Presidential Delimitation Commission is appointed to determine whether or not the number of constituencies should be increased. Each constituency is divided into wards or council seats, which are contested in each general election. The advantage of this system is that parliamentarians and councillors are accountable to their constituents - including those who did not vote for them. The major disadvantage is that there is a skewed representation of opposition parties in Parliament. For instance, the main opposition party - the Botswana National Front - polled 37\% of the national vote in the 1994 general election but only had $11 \%$ representation in Parliament. The same skewed representation was replicated in local political authorities, which, in Botswana, are known as councils. This defect apart, the system has worked very well thus far.

\section{Background to Democratic Success}

Four principal factors have influenced Botswana's relative democratic success. These are:

- Historically, Tswana society has been run on the basis of consensual democracy. In each of the former autonomous Tswana chiefdoms (these, as well as non-Tswana-speaking ethnic groups were amalgamated into a single nation at independence) there was - and still is - a tribal assembly point where male adults debate and resolve major political and administrative issues in a meeting presided over by the chief.

- Botswana's political elite is very small by international standards. The members of this elite are, by and large, related either by marriage or by tribal totem. It is also drawn from people who went to school together at primary, secondary and tertiary education levels.

- Botswana has a long history of capable state administration. As is now well established, successful democracies rest on a capable state. Both the modern and pre-colonial Tswana states are and have been very strong. Indeed, there is consensus among scholars both within and outside Botswana that the Botswana state is an exception in sub-Saharan African in that it is a developmental state - a factor that sets it apart from the soft, weak, predatory and vampire states in most of the sub-continent.

- The fourth, and perhaps critical, factor is economic success. Since the discovery of minerals, especially diamonds, in the late 1960s, Botswana has enjoyed tremendous economic growth and development. This observation is validated by its human development index. Until the onset of the AIDS/ HIV pandemic, Botswana's human development ranking was higher than those of most African countries.

The essential point is that democracies are founded upon socio-economic development. Without that, there is little prospect of democratic consolidation. 
Comparative examples here are Mauritius and the Gambia, which, with Botswana, are arguably the oldest democracies in sub-Saharan Africa.

Botswana and Mauritius are successful liberal democracies because they have been successful on the economic-developmental front. This is not the case with the Gambia, which consequently suffered a democratic reversal through a military coup in the early 1990s.

Two other factors have influenced Botswana's political stability. One is that, historically, the state has not been the only avenue of accumulation of wealth. Cattleraising and other private sector pursuits have long paralleled the state. This has had the effect of mitigating political competition. Political competition has not been a life and death matter, as is, perhaps, the case in poorer societies such as Lesotho.

The second is the country's relative ethnic homogeneity. Close to $80 \%$ of the population is drawn from the Tswana ethnic group. And, let it be said, the norm in Tswana society is to resolve political disputes by negotiation and compromise and not by physical confrontation. In sum, Botswana is a successful liberal democratic society because of sound management and a strong developmental state.

\section{CONCLUSION}

This paper is by no means exhaustive in terms of the role, functions and performance to date of the IEC. What it has done is to outline the salient points that account for the sterling performance of the Commission.

Botswana's electoral system has served the country very well to date and Batswana understand it. It is therefore very unlikely that it will be changed. If anything, stakeholders want to improve it and make it more inclusive. Hence the reduction of the voting age from 21 to 18 . Other improvements, such as the $30 \%$ quota for women in all political parties, are in process and will hopefully bear results in the fullness of time. Here the major issue is gender balance, preferably of the Nordic type.

We believe Botswana offers invaluable lessons to its sister African countries, especially on how to blend successfully modern democratic governance with traditional political institutions such as chieftainship. 